\title{
Batman'da Sokakta Çalış(tırıl)an Çocuklar ve Karşı Karşıya Olduklari Riskler
}

\author{
DOI: 10.26466/opus.580524 \\ *
}

\section{Emrullah Türk*}

* Dr, Öğr. Üyesi, Batman Üniversitesi, Fen-Edebiyat Fakültesi, Batı Raman / Batman/ Türkiye E-Posta: dremrullahturk@gmail.com ORCID:0000-0002-2464-2556

\section{Öz}

Göç, yoksulluk ve kentleşmenin sonuçlarından biri olan sokakta çalış(tırll)an çocuklar olgusu, Türkiye'de başta büyükşehirler olmak üzere birçok kentin karşı karşıya olduğu sorunlardandır.Bu çalışma, Batman'da sayıları hızla artan sokakta çalş̧(tırl)an çocukların demografik ve sosyo-ekonomik durumlarını ortaya koymayı, çalış(tırll)ma nedenlerini ve sokakta doğabilecek muhtemel riskleri öngörerek çözüm önerileri sunmayı amaçlamaktadır. Öte yandan bu çalışma, çocukların sokakta çalış(tırıl)ma nedenlerinden biri olan kentsel yoksulluğa dikkat çekmektedir. Araştırmaya, Batman kent merkezinde ikamet eden ve amaçl örneklem tekniği ile belirlenen 129 çocuk katılmıştır. SPSS aracılığıyla elde edilen veriler ışığında değerlendirmeler yapılmıştır. Araştırma bulgularına göre, yoksul ailelere mensup olan çocukların büyük bir bölümü hem eğitim hayatlarına devam etmekte hem de sokakta çalş(tırll)maktadır. Bu çocuklarmn ebeveynlerinin eğitim düzeyi ise düşüktür. Genelde düzensiz bir gelir elde eden bu çocuklar, sokakta her an tehlike velveya risklerle karşı karşıyadır. Öte yandan bu çalışma, günden güne sayıları artmakta olan sokakta çalış(tırıl)an çocukların ileriki yıllarda sokak çocuklarına dönüşme riskine dikkat çekerek öneriler sunmaktadir.

Anahtar Kelimeler: Sokakta çalış(tırıl)an çocuklar, Kentsel Yoksulluk, Göç, Kentleşme, Batman. 


\title{
Children Working/Worked in The Street in Batman and Risk They Face
}

\begin{abstract}
The phenomenon of children working/worked in the streets, which is one of the consequences of migration, poverty and urbanization is one of the problems faced by many cities, especially metropolitan centers in Turkey. The aim of this study is to present the demographic and socio-economic conditions of the children whose number is increasing and who are working/worked by force in Batman streets, the reasons of their employment and the possible risks they face in the streets. On the other hand, this study draws attention to urban poverty, which is one of the reasons why children work on the street. A total of 129 children living in Batman city center were involved. In the light of the data obtained through SPSS, evaluations were made. According to the research findings, a large part of the children belonging to the poor families continue their education and also work on the streets. The education level of the parents of these children is low. These children, who usually have an irregular income, face dangers and / or risks on the street at any time. On the other hand, this study draws attention to the risk of these children's, the number of whom are increasing day by day, becoming into street children in the following years and offers suggestions.
\end{abstract}

Keywords: Children who are working/worked by force, Urban poverty, Migration, Urbanization, Batman 


\section{Giriş}

Çocukluk, insan hayatında önemli bir dönemdir. Bu dönemde birey, biyolojik, psikolojik, sosyal ve kültürel birçok açıdan hızlı bir gelişim gösterir. Ebeveyn ile başlayan ilk temasın ardından yakın çevre ve akranlarla kurulan ilişkiler, çocuğun ileriki dönemlerine de etki edecek bir sosyalleşme sürecini doğurur. Çocukların bu süreçte ebeveynleriyle kurduğu iletişim ve hayatın farklı alanlarına dair ebeveynlerden alınan desteğin niteliği, çocuğun geleceğe dair beklentileri üzerinde belirleyici olmaktadır. İşte bu dönemde birçok alanda ebeveynlerinin desteğinden yoksun bazı çocuklar, göç ve yoksulluk gibi bir takım nedenlerden dolayı sokakta çalış(tırıl)makta ya da sokakta yaşamaktadır. Genel anlamda, çocuk işçi ve sokak çocuğu diye tanımlanan bu çocuklara sıklıkla gelir dağılımının adaletsiz olduğu, az gelişmiş ve gelişmekte olan ülkelerde rastlanmaktadır. Bununla birlikte bu çocukların sayıları da kesin olarak bilinmemektedir.

Uluslararası Çalışma Örgütü (ILO) çocuk işçiliğini, "Çocukları çocukluklarını yaşamaktan alıkoyan, potansiyellerini ve saygınlıklarını eksilten, fiziksel ve zihinsel gelişimlerine zarar verici işlerde istihdam edilmesi" (ILO, 2018) olarak tanımlanmaktadır. Ancak Uluslararası Çalışma Örgütü (ILO) tarafından çocukların yaptıkları işlerin hepsi, ortadan kaldırılmak istenilen çocuk işçiliği kategorisine konulmamaktadır. Çocukların ve ergenlerin sağlıklarına ve kişisel gelişimlerine zarar vermeyecek ya da eğitimlerini aksatmayacak işler yapmalarına genellikle olumlu bakılmaktadır. Örneğin, evde anne ve babalarına yardımcı olmak, aile işletmesinde belirli işler yapmak, okul saatleri dışında ve tatillerde cep harçlığı sağlayacak kimi işlerde yer almak gibi bu tür etkinliklerin çocukların gelişimine ve ailelerinin durumuna katkıda bulunduğu, onlara çeşitli beceriler ve deneyim kazandırdığı; yetişkinlik dönemlerinde toplumun üretken üyeleri olmaya hazırladığı (ILO, 2018) savunulmaktadır.

ILO tarafından yapılan çalışmaya göre 2000-2012 yılları arasında küresel düzeyde çocuk işçi sayısı azalma eğilimindedir. Buna göre 2000 yılında küresel düzeyde çocuk işçi sayısı 246 milyon iken; 2012 yılında bu sayı 168 milyona (Yaklaşık 100 milyon erkek ve 68 milyon kız çocuk işçi) düşmüştür. Aynı çalışmada küresel düzeyde çocuk işçi sayısının 
2020 yılında 107 milyona kadar düşeceği öngörülmektedir (ILO, 2013, s.13) Buna göre ILO'nun bu çalışmasında, küresel düzeyde erkek çocuk işçi sayısı kız çocuk işçi sayısından fazladır.

Bir takım kültürel kodlar ve toplumsal değerlerin etkisiyle -Türkiye'de ev içi gündelik işlerde annelerin en büyük yardımcısı konumunda olan- kız çocuklarının, sokaklarda erkeklere oranla daha az çalıştırıldığı gözlemlenmektedir. Bununla beraber, Türkiye'de de sokakta çalış(tırıl)an kız ve erkek çocukların sayısı kesin olarak bilinmemektedir.

Türkiye'de 1950'li yıllardan itibaren kırsal alanlardan kentlere yönelen göçlerin kentlerde istihdam olanakları bakımından emilebilecek boyutları aşmasıyla artan kentsel yoksulluk artmıştır. Kentsel yoksulluk, bir yandan enformel sektörde çalışan sayısının artışına bir yandan da sokakta çalış(tırıl)an çocuk sayısının hızla artmasına neden olmuştur. Türkiye'nin başta büyükşehirleri olmak üzere diğer tüm kentlerinde, gelir dağılımındaki adaletsizlik, bölgeler arası eşitsizlik, zorunlu olarak gerçekleşen içgöçler gibi birçok nedenden dolayı artan kentsel yoksulluk, farklı görünümler ve oranlarda kendini tekrar eden bir fotoğraf karesine dönüşmüştür. Sokakta çalış(tırıl)an çocuklar gerçeği de bu fotoğraf karesinin bir kısmını oluşturmaktadır.

Sokakta çalış(tırıl)an çocuk sayısının hızla artması, ailelerin artan yoksulluğunun etkilerine en görülür tepkidir. Bu çocukların birçoğu okula düzensiz gitmekte ve öncelikli olarak sokaklarda çalışmakta, eğitimleri de kaçınılmaz olarak ikinci sırayı almaktadır. Sokaklar hayatlarının büyük bir parçası olsa da bu çocukların çoğu hala aileleriyle yaşamaktadır ve yoksullukları ailelerinin durumundan kaynaklanmaktadır (Unicef, 2006).

\section{Sokakta Çalış(tırıl)an Çocuklar}

\section{Çocuklar Sokakta Çalışmaya Sürükleyen Nedenler ve Çocuklarn Sokaklarda Bekleyen Muhtemel Tehlikeler/Riskler}

Çocukların herhangi bir işte çalıştırılması yalnızca günümüze özgü bir uygulama olmayıp, uzun bir geçmişe dayanmaktadır. Sanayileşme öncesi, tarım toplumlarında çocukların çalıştırılması pek çok kültür için 
doğal ve yaygın bir uygulama olarak görülmüştür (Duyar ve Özener, 2003, s.11). Sanayileşmeyle birlikte, tarım dışı alanlarda çocuk işçiliğinde hızlı bir artış yaşanmaya başlamıştır. Bununla birlikte göç ve yoksulluk gibi gerekçelerden dolayı kentlerde sokakta çalış(tırıl)an çocuklar gerçeği de hızla yayılmaya başlamıştır.

Dünya genelinde sayıları her geçen gün artan sokakta çalış(tırıl)an çocuklar gerçeği, neden ve sonuçları açısından karmaşık bir olgudur. Henüz üzerinde uzlaşılan evrensel bir tanımı da bulunmamaktadır. Bu muğlaklık, meselenin farklı coğrafyalarda ve kültürlerde farklı şekillerde karşlılk bulmasından yani birbirinden farklı toplumların varoluşundan kaynaklanmaktadır. Her ne kadar üzerinde uzlaşılan bir tanım olmazsa da, Birleşmiş Milletler Çocuklara Yardım Fonu (UNICEF) tarafından yapılan bir tanımın bu konuya ilişkin yazında sıkça kullanıldığ 1 görülmektedir. Buna göre Birleşmiş Milletler Çocuklara Yardım Fonu "sokak çocuklarımı, zamanlarının büyük bir kısmını sokakta geçiren, herhangi bir korumadan ve yetişkinlerin doğrudan desteğinden yoksun çocuklar" olarak tanımlamaktadır. Bu çocuklar, aileleriyle kurdukları ilişki ve sokağı kullanım temeline göre üç kategori altında incelenmektedir. Birinci kategoride, sokakta çalış(tırıl)an ve birlikte yaşadıkları aileleriyle düzenli bağı olan ve onlarla yaşayan ancak "sokağa aday" çocuklar; ikinci kategoride, yetersiz ve düzensiz aile desteğine sahip ancak "sokakta bulunan" çocuklar; son kategoridekiler ise, "sokağın çocukları" olarak nitelendirilen, sokağı mesken edinmiş, çoğunlukla madde bağımlısı olan ve aile desteği olmayan çocuklardır (UNICEF, 1988 akt. Altuntaş, 2014, s.12).

Ankara'da sokakta çalışan çocukların yaşam dünyasına eğilen bir çalışmada, UNICEF'in "sokak çocukları" genel kavramsallaştırması eleştirilmektedir. UNICEF her ne kadar genel kavramsallaştırmayı, sokaktaki tüm çocuk gruplarına eşit ve etkin bakım dağıtımı için yaptığını ileri sürse de bunun doğru bir kavramlaştırma olmadığı savunulmaktadır (Altuntaş, 2014, s.12). Çünkü her ülkede sokağın içerdiği anlam, sokaklarda bulunan çocuk gruplarının nitelikleri, sokakta bulunma nedenleri, faaliyet alanları açısından farklılaşabilmektedir. Bu çocukların birbirlerinden çok farklı niteliklerinin varlığına karşın, sokak çocukları üst kimliği altında toplanmaları, farklı dezavantajlı çocuk 
gruplarına yönelik olarak verilecek bakımlarda engeller oluşturmaktadır (Bilgin, 2012, s.82).

Altuntaş (2014, ss.12-27) UNICEF'in genel kavramsallaştırmasının bu olguya dair açılama alanını genişletmediğini, aksine sorununun boyutları ve çözüm önerileri noktasında tıkanıklığa yol açtığını söylemektedir. Ankara'da yaptı̆̆ı çalışmasında da "sokakta çalışan çocuk" kategorisini "sokak çocukları" genel kavramının etki alanı dışında bağımsız bir kavram olarak kullandığını özellikle vurgulamaktadır. Bu çalışmada da Batman sokaklarında iradeleriyle ya da aile veya çevrenin yönlendirmesiyle çalışan ya da çalıştırılan çocuklar "sokakta çalış(tırıl)an çocuklar" kategorisi altında ve "sokak çocukları" genel kavramsallaştırmasından bağımsız bir kavram olarak kullanılmaktadır. Çünkü, Batman'da “sokakta çalış(tırıl)an çocukların geneli aile bütünlüğünün korunduğu ve ebeveyn ile çocuklar arasında nitelik açısından tartışılabilir olsa da düzenli bir ilişkinin var olduğu bir ortamda hayatlarını sürdürmektedirler.

Daha önce yapılan bazı çalışmalarda da (Karataş vd., 1994; İlik ve Türkmen, 1994; Karatay, 1999) görüldüğü üzere aile bütünlüğü ve düzenli bir ilişkinin varlığı bu çocukları sokakta yaşayan çocuklardan ayıran temel belirleyicilerdir. Bu nedenle UNICEF'in yaptığ1 "sokak çocukları" tanımı, hem sokakta çalış(tırıl)an hem de sokakta yaşayan geniş bir çocuk grubunu kapsadığından bu genel kavramsallaştırma çalışma örneklemimizi karşılamamaktadır.

Sokakta çalış(tırıl)an çocuklar olgusu, başta ekonomik olmak üzere, sosyal ve kültürel bir takım nedenlere dayanmaktadır. Güneş ve Kalaycı (2004, s.7) çocuğu sokağa iten nedenleri şu şekilde sıralamaktadır:

- İşsizlik

- Yaşanan yoğun içgöçler

- Ekonomik yoksunluk-yoksulluk

- Gelir dağglımında yaşanan adaletsizlik

- Ailenin olumsuz tutum ve davranışları

- Ebeveyn ve çocuğun eğitim yetersizliği

- Zorla sokakta çalıştırılma

- Arkadaş gruplarının olumsuz etkisi

- Aile içi şiddet, cinsel taciz, tecavüz, ihmal ve istismar

- Ailenin parçalanması, sevgi ve ilgi yetersizliği 
- Çarpık kentleşme sorunları

- Sokağın çekiciliği ve özgürlüğü

- Çocuğun sokakta çalışıp para kazanmasını teşvik edici kültürel öğeler

- Medyanin olumsuz yayınları

- Denetimsiz oyun salonlarının çekiciliği

- Yetişkinlerin acıma duygularıyla çocuklara sokakta rastgele para ve eşya verme gibi olumsuz tutum ve davranışları

- Kimi gönüllü kuruluşların yetersiz bilgi-profesyonel yaklaşım eksikliği nedeniyle medyatik çalışma gayretleri gibi olumsuz tutum-davranışları şeklinde sıralanabilir. Ayrıca,

- Çocuk haklarının yeterince hayata geçirilememiş olması (Kuçur, 2016, ss.60-61) ile

- Kırsal kültürün çocuğu tanımlayan işgücü anlayışı (Kömürcü ve Avşar Negiz, 2016, s.976) gibi nedenlerin de çocuğun sokakta çalışmasında etkili olabildiği görülmektedir.

Güneş ve Kalaycı (2004, s.7) çocukları sokakta bekleyen tehlikeleri ise şu şekilde sıralamaktadır:

- İhmal ve istismara uğrama

- Çocukların sigara, bali, tiner gibi bağımlılı̆̆a yol açan maddeleri kullanması

- Zihinsel ve fiziksel gelişiminde gerileme

- Şiddete maruz kalma (dayak, yaralama, ölüm vb.)

- Sokakta bulunmanın verdiği mekândaki bağımsızlık hissinin çocukları, hırsızlık, gasp, fuhuş gibi suçlara yöneltmesi

- Psikolojik sorunlar

- Kazalara maruz kalma

- Eğitim ve sağlık sorunları gibi tehlikeler ortaya çıkabilmektedir.

Türkiye'de sokakta çalış(tırıl)an çocuklar olgusu büyük oranda, 1950'li yıllardan itibaren artan içgöçler ve kentleşmeyle alakalıdır. Bu dönemden itibaren artan içgöçler ve kentleşme ise birçok faktöre dayanmaktadır. Bu nedenle Türkiye' de kentleşme ve içgöç olgusu tek bir kuram çerçevesinde değerlendirilemeyecek kadar çok yönlü bir yapı arz etmektedir. 
Hızlı kentleşme ve içgöçlerle birlikte kentlere yönelen ailelerde, yoksulluk ve kentle bütünleşme sorunu başta olmak üzere bir takım sorunlar ortaya çıkmaya başlamıştır. Sokakta çalış(tırıl)an çocuklar olgusu da bu sorunlardan biridir. Bu bağlamda sorunun ortaya çıkma nedenlerinden biri olan göç olgusu ve bu olguya dair ortaya konulan kuramların irdelenmesi önem arz etmektedir.

Ekonomik, sosyal, kültürel ve politik gibi birtakım nedenlerle gerçekleşen göç süreçlerini açıklamaya yönelik, 19. ve 20. yüzyıllarda birçok kuram geliştirilmiştir (Develi, 2017, s.1344). Çalışma konusuyla alakalı olarak birçok kuram arasından Ravenstein'in göçe dair genel geçer kanunlar olarak belirttiği yedi madde, Everett Lee'nin itme-çekme kuramı ve Petersen'in göç tiplerine kısaca değinilmiştir.

İlk olarak Ravenstein'ın 1871 ve 1881 yılı İngiliz nüfus sayımı istatistik verilerinin üzerine kurduğu ve bu verilerden yola çıkarak ortaya koyduğu yedi göç kanunu (Çağlayan, 2006, ss.68-69) göç ile ilgili ilk çalışma niteliği taşımaktadır. Bu nedenle daha sonraki göç kuramlarına da öncülük etmiştir (Adıgüzel, 2016, s.23). Ravenstein, göç eğiliminde özellikle mesafenin önemine dikkat çekmiştir. Farklı nedenlerden dolayı göç etme eğiliminde bulunan bireylerin genellikle kısa mesafeli alanlara doğru göçü tercih ettiğini vurgulamıştır. Petersen'in ise, göç olgusunu ilkel göçler, zoraki ve yönlendirilen göçler, serbest göç ve kitlesel göç olarak dört temel kategoride ele almıştır. Lee'nin itme-çekme kuramına göre ise, göçler ekonomik, sosyal, kültürel ve ailevi gibi bir takım itici ve çekici faktörlerin etkisiyle gerçekleşmektedir (Yalçın, 2004, ss.14-31).

Ravenstein'in göç olgusuna dair genel geçer kanunları ve göç sürecinde mesafeye vurgusu ile Petersen ve Lee'nin kuramları, çalışma kapsamında şu şekilde değerlendirilebilir: Batman kentleşmesi büyük ölçüde Ravenstein'in belirttiği yedi maddeden biri olan yakın çevreye doğru yönelim ile Petersen'in ifade ettiği serbest ya da yönlendirilen içgöçlere dayanmaktadır. Ayrıca Lee'nin kuramı bağlamında Batman'a yönelen içgöçlerde petrol rafinerisinin kurulması çekici bir faktör olarak; kırsal alanlarda yaşanan ekonomik, sosyal ve siyasal bir takım sıkıntılar da itici faktörler olarak değerlendirilebilir.

Batman, 1950'li ylllardan itibaren başlayan içgöçlerin varettiği kentleşmeyle birlikte sokakta çalış(tırıl)an çocuk sayısının arttığı ve hızla 
bir soruna dönüştüğü bir kent görünümündedir. Batman'da sokakta çalış(tırıl)an çocuklar, genel olarak aile bütçesine katkı sağlamak amacıyla kentin farklı noktalarında ${ }^{1}$ çalışmaktadır. Çocukların iş tercihlerine bakıldığında, mevsime göre değişen işler (kağıt mendil,yeşil nohut satışı vb.) ile yöresel (karpuz çekirdeği satışı, toptancılardan alınan malzemelerin taşınması için el arabacılığı gibi) işler ön plana çıkmaktadır. Bu işlerin yanında karton toplayıcılığı da en çok yapılan işlerdendir. Ayrıca su satıcılığı, simitçilik, boyacılık gibi işler de sokakta çalış(tırıl)an çocukların en çok rağbet ettikleri işlerdendir.

Kentin büyümesi ve sokakta çalış(tırıl)an çocuk sayısının artmasıyla beraber birçok sorun ortaya çıkmaktadır. Çocukların sokaklarda bulunma süresi uzadıkça, aile ile olan bağları hızla kopabilmekte; çocuklar için cam sildikleri, çekirdek sattıkları arkadaşları çocukların yeni ailesi formuna bürünebilmektedir. Bu süreçte kurulan yeni ilişki ağları, çocuğu para kazanabilmek için çevreyi rahatsız edici davranışlara da itebilmektedir. Ardından akranlarının etkisiyle ya da bir takım illegal gruplar tarafından çocuklar suça sürüklenebilmektedir.

Sokakta çalış(tırıl)an çocuklar, akranlarının etkisiyle merak ve denemeyle başlayan, başta sigara olmak üzere bir takım uçucu ve uyuşturucu maddelerin kullanımından kaynaklı bağımlılık riskiyle karşı karşıya kalabilmektedir. Bu tür bağımlılıklar, bireylerde nörolojik ve psikiyatrik etkilerin yanında toplumsal anlamda bir takım sorunlara da yol açabilmektedir.

Sokakta çalış(tırıl)an çocuklar, dışarda para kazanmanın verdiği mutluluk ile bu süreyi bazen iradi bazen de zorunlu olarak uzatabilmektedir. Bu durum okula devam noktasında ilgiyi azaltabilmekte ve bir süre sonra çocuklar okulu terk edebilmektedir.

Özellikle büyükşehirlerde trafik akışının yoğun olduğu caddelerde cam silen çocukların her an bir kazaya maruz kalma ya da kazaya sebep olma risklerini göz ardı etmemek gerekir. Çocukların zorlayıcı bazı davranışlarından kaynaklı olarak sürücülerle fiziki şiddet boyutunda karşı karşıya geldikleri sahnelere ise her gün şahit olunmaktadır.

\footnotetext{
${ }^{1}$ Sokakta çalış(tırıl)an çocuklara, daha çok kentin en işlek bulvarı olan Turgut Özal Bulvarı ile toptancı esnafinın yoğun olarak yer aldığı kentin ilk yerleşim yeri olan "Çarşı/meydan" olarak adlandırılan yerlerde rastlanmaktadır.
} 
Sabit bir iş yerinde çalışan çocuk işçilerle kıyaslandığında, sokakta çalış(tırıl)an çocukların sabit bir çalışma yerinin olmaması başka riskileri de doğurabilmektedir. Örneğin; bir cadde üzerinde ya da bir otobüs durağında savunmasız bir şekilde bulunan bu çocuklar her an yaşayabilecekleri sözlü bir tartı̧̧mada şiddet uygulayan-uygulanan taraf olabilmektedir.

Sokakta çalışmalarından dolayı her türlü ihmalin ve istismarın yaratabileceği tehditleri göz önünde bulundurarak bu çocukların toplumsal olarak korunmaları ve geleceğe hazırlanmalarını sağlamak büyük bir önem arz etmektedir. Sorunun çözümü için ilk adım ise bu çocukları ve sorunlarını bütünüyle tanımaktır (Şişman, 2006, s.252) İşte bu gerçeklik ise mevcut durum tespiti gerektirdiğinden, çocukların sokakta çalış(tırıl)ma nedenleri, koşulları ve sokakta çalış(tırıl)ırken karşı karşıya oldukları muhtemel riskleri ilk ağızlardan duymak büyük bir önem arz etmektedir.

\section{Araştırmanın Yöntemi}

$\mathrm{Bu}$ çalışma, nicel araştırma yöntemine dayanmaktadır. Araştırmada veri toplama amacıyla anket formu kullanılmıştır. Araştırmanın sorunsalını, Uluslararası Çalışma Örgütü'nün (ILO) ortadan kaldırılmak istenilen çocuk işçiliği kategorisine konulamayan, enformel sektörde yer alan ve sabit bir mekana bağlı kalmayan sokakta çalış(tırıl)an çocukların sokakta çalışma nedenleri, iç göçün bu durum üzerindeki etkileri oluşturmaktadır. Bu sorunsal bağlamında araştırmanın temel amacı, Batman'da gün geçtikçe sayıları hızla artan sokakta çalış(tırıl)an çocukların genel profillerini ortaya çıkararak çocukların çalışma koşullarını ve sokakta çalış(tırıl)malarından kaynaklanabilecek riskleri incelemek, çalışma nedenlerini ön plana çıkarmak ve bu soruna öneriler sunmaktır. Bu çalışmada, çocukluk döneminde sokakta çalış(tırıl)manın temel nedeninin, üyesi oldukları ailenin güvencesiz işlerden dolayı düşük gelir düzeyine sahip olmalarından kaynaklandığı hususu araştırmanın temel varsayımını oluşturmaktadır. Çünkü düşük bir gelire sahip ailelerde, çocukların aile bütçesine katkı sağlamak için iradi ya da aile yönlendirmesiyle sokaklarda çalışması sık rastlanan bir durumdur. 
Araştırmanın evrenini Batman kent merkezi içinde yer alan 17 yaş ve altındaki sokakta çalış(tırıl)an çocuklar oluşturmaktadır. Evrenin mümkün olduğunca en doğru şekilde tespit edilebilmesi için Batman Belediyesi Zabıta Müdürlüğü yetkililerine danışılmış, net olmamakla beraber 350-400 civarında sokakta çalış(tırıl)an çocuğun sabit sayılabileceği yetkililerce ifade edilmiştir. $\mathrm{Bu}$ bilgilerden hareketle uygulama dönemi olarak eğitim-öğretimin sürdüğü Mayıs ayı seçilmiştir. Böylece çocukların okulla olan bağlarının devam edip etmediği de daha net anlaşılmıştır.

Öncelikle pilot uygulama gerçekleştirilerek sorulara ilişkin oluşabilecek sorunların önüne geçilmiş ve anket formu yeniden düzenlenmiştir. Pilot uygulama sonrası son halini alan anket formunun uygulaması Mayıs ayı boyunca hafta sonlarında, sokakta çalış(tırıl)an çocuklarla kentin en işlek (Turgut Özal Bulvarı'nda, toptancı esnafının yoğun olarak yer aldığı kentin ilk yerleşim yeri olan Aydınlıkevler, Çarşı, Cumhuriyet ve Meydan olarak adlandırılan) yerlerinde, 8 sosyolog$^{2}$ tarafından katılımcılarla yüz yüze gerçekleştirilmiştir.

Nicel araştırma çerçevesinde Batman kent merkezinde ikamet eden ve seçkisiz olmayan amaçlı örneklem kapsamında anket tekniğiyle çoğunluğu erkek (126 kişi) ve yaşları 7-17 arasında değişen toplam 129 katılımcıya ulaşılmıştır. Bu yolla elde edilen veriler, SPSS aracılığıyla frekans tablolarına dönüştürülmüş ve değerlendirmeler yapılmıştır. Araştırmanın amaçları doğrultusunda sokakta çalış(tırıl)an çocukların sosyo-demografik özellikleri, aile yapıları, onları çalışmaya iten nedenler ve sokakta çalışmalarından kaynaklı muhtemel risklerin neler olduğu belirlenmeye çalışılmıştır.

Sokakta çalış(tırıl)ma, uluslararası bağlayıcı kararlar çerçevesinde hukuki manada bir suç olarak tanımlandığından ve cezalandırılma korkusundan dolayı ailelere ulaşma çabamız daha başlangıç aşamasından itibaren (pilot uygulama sırasında) olumsuzlukla sonuçlanmıştır. Bu nedenle sokakta çalış(tırıl)an çocuklara ilişkin bazı konularda (özellikle içgöç deneyimine ilişkin hususlar) sağlıklı veriler elde edilememiştir.

\footnotetext{
$2 \mathrm{Bu}$ çalışma sürecinde, haftasonlarında uygulama gerçekleştiren ve adlarım burada tek tek zikredemediğim tüm sosyolog arkadaşlarıma teşekkür ederim.
} 
Araştırma kapsamında Batman'da sokakta çalış(tırıl)an çocukların çoğunlukla nerelerde çalıştığını tespit etmek için gözlem yapılmış ve sokakta çalış(tırıl)an çocukların kentin muhtelif bölgelerinde yoğunlaşttğı görülmüştür. Anket uygulamaları öncesi çocukların rızaları alınarak çalışmada isimlerinin yer almadığı, kendilerini rahat hissetmeleri ve bu çalışmanın bilimsel amaçlar dışında kullanılmayacağı uygun bir dille ifade edilmiştir. Etik kurallar kapsamında yapılanlar bilgilendirme akabinde, uygulama çocuklarla yüz yüze gerçekleştirilmiştir.

Araştırma, sokakta çalış(tırıl)an çocuklar sorununa dikkat çekme adına önem arz etmektedir. Çocukların sosyo-demografik özelliklerinin, aile yapılarının, onları çalışmaya iten nedenlerin ve karşı karşıya kaldıkları risklerin neler olduğunun ortaya çıkarılması, bu soruna ilişkin çözüm önerilerinin geliştirilmesi bakımından önemlidir.

\section{Araştırmanın Bulguları}

\section{Sosyo-demografik Özellikleri}

Batman kent merkezinde 129 katılımcı ile gerçekleştirilen anket verilerine göre sokakta çalış(tırıl)an çocukların \%97,7'si erkek ve \%2,3'ü kızlardan oluşmaktadır. Ülkemizde yapılan benzer çalışmalara (bkz. Atauz, 1998; Karatay, 1999; Altuntaş, 2014) da bakıldığında erkeklerin kızlara oranla sokakta çalış(tırıl)an çocuklar arasında daha baskın olduğu görülmektedir. Ailelerin kız çocuklarını sokakta çalıştırma noktasında erkeklere oranla daha temkinli-koruyucu davrandıkları ve toplumsal bir takım değerlerin bu noktada belirleyici olduğu görülmektedir. Toplumun büyük çoğunluğunun, kız çocuklarının sokaklarda çalıştırılmasına onay vermemesi, sokakta çalış(tırıl)an kız çocuğu sayısında belirleyici olmaktadır ${ }^{3}$.

Çocukların yaş dilimleri aralığına bakıldığında, \%62,1'inin 11-14 yaş grubunda olduğu görülmektedir. Bu grubu \% 28,8 ile 15-17 yaş grubunun izlediği görülmektedir. 7-10 yaş grubunun evren içerisindeki

\footnotetext{
${ }^{3}$ Geçici koruma altında bulunan ve son zamanlarda Batman sokaklarında sıklıkla görülen sokakta çalış(tırıl)an Suriyeli çocuklar, bu çalışma kapsamı dışında tutulmuştur.
} 
oranı ise \% 9,3 olarak gerçekleşmiştir. Tüm bu veriler, sokakta çalış(tırıl)an çocukların çoğunluğunun ergenlik öncesi dönemde ve zorunlu eğitim çağında olan bireylerden oluştuğunu göstermektedir.

Tablo 1: Katılımcıların Ĕ̆itim Durumu

\begin{tabular}{lll}
\hline Eğitim Durumu & Frekans & Yüzde (\%) \\
\hline Okur-yazar değil & 3 & 2,3 \\
İlköğretim & 99 & 76,7 \\
Ortaöğretim & 21 & 16,3 \\
Diğer(herhangi bir kademede okulu birakanlar) & 6 & 4,7 \\
Toplam & $\mathbf{1 2 9}$ & $\mathbf{1 0 0}$ \\
\hline
\end{tabular}

Sokakta çalış(tırıl)an çocukların büyük bir kısmı (\% 93) okula devam etmektedir. Yani çocuklar günün bir kısmını okulda diğer bir kısmını ise sokaklarda çalışarak geçirmektedir. Okulu bırakanların oranı \% 4,7 olarak tespit edilmiştir. Ekonomik yetersizlik, okula karşı isteksizlik ve arkadaş etkisi gibi etkenler, çocukların okulu bırakma nedenleri olarak siralanmaktadır.

Aynı şekilde, bir eğitim kurumuna devam eden çocukların \% 76,7'si ilköğretim düzeyinde olan okullara devam etmektedir. Geriye kalan \% 16,3'ü de ortaöğretim kurumlarına devam eden çocuklardan oluşmaktadır. Veriler neticesinde Batman'da sokakta çalış(tırıl)an çocukların büyük bir bölümü, okula devam ile sokakta çalışmayı bir arada yürütmektedir. Ancak yarı yıl ve yıl sonu tatilleri döneminde okulda geçirilen sürenin de sokaklarda geçirilen süreye eklendiği çocuklar tarafından ifade edilen bir başka gerçektir.

\section{Ailelerin Sosyo-Ekonomik Özellikleri}

Sokakta çalış(tırıl)an çocukların ailelerine ilişkin verilere bakıldığında, ebeveynlerin \%96,1'inin ikisinin de sağ ve beraber oldukları sonucuna ulaşılmaktadır. İkisi de sağ ve ayrı olanların oranı \%2,3'tür. Katılımc1 çocuklardan sadece bir çocuğun annesi ve bir diğerinin ise babası vefat etmiştir. Bu verilere göre Batman'da sokakta çalış(tırıl)an çocuklar üzerine bir değerlendirme yapıldığında parçalanmış aile üzerinden bir durum tespiti yapmak zordur. 
Tablo 2: Katılımcı Ebeveynlerinin Ĕ̆itim Durumu

\begin{tabular}{lllll}
\hline & \multicolumn{2}{l}{ Baba Eğitim Durumu } & \multicolumn{2}{l}{ Anne Eğitim Durumu } \\
\hline Eğitim Düzeyi & Frekans & Yüzde (\%) & Frekans & Yüzde (\%) \\
Okur yazar değil & 24 & 18,6 & 52 & 40,3 \\
Okuryazar & 17 & 13,2 & 23 & 17,8 \\
İlkokul/ortaokul & 65 & 50,4 & 35 & 27,1 \\
Lise & 12 & 9,3 & 1 & 0,8 \\
Lisans & 4 & 3,1 & 1 & 0,8 \\
Diğger(Bilmiyorum) & 7 & 5,4 & 17 & 13,2 \\
Toplam & $\mathbf{1 2 9}$ & $\mathbf{1 0 0}$ & $\mathbf{1 2 9}$ & $\mathbf{1 0 0}$ \\
\hline
\end{tabular}

Sokakta çalış(tırıl)an çocukların ebeveynlerin eğitim düzeyi bu araştırmada ele alınan bir diğer değişkendir. Tablo 2'deki verilere bakıldığında, ebeveyn eğitim düzeylerinin genel olarak düşük olduğu görülmektedir. Annelerin eğitim düzeyine bakıldığında \% 40,3'ünün okur-yazar olmadığı, \% 17,8'inin sadece okur-yazar olduğu, \% 27,1'inin ilkokul ve ortaokul mezunu olduğu, $\% 0,8^{\prime}$ inin lise ve $\% 0,8$ 'inin lisans düzeyinde bir diplomaya sahip olduğu görülmektedir. Katılımcılardan $\% 13,2$ 'si annesinin eğitim düzeyini bilmemekte ya da hatırlamamaktadır. Babaların eğitim düzeyi, annelerin eğitim düzeyine oranla daha yüksek görünse de genel anlamda babaların eğitim düzeyi de oldukça düşük çıkmıştır.

$\mathrm{Bu}$ çalışma kapsamında örneklem grubun büyük çoğunluğunun erkeklerden oluşmasından dolayı sokakta çalış(tırıl)an kız çocuklarının eğitimi ile ilgili önemli bir veriye ulaşılamamıştır. Ancak araştırmacı tarafından Batman'da yapılan bir başka çalışmada ise eğitimin neredeyse tüm kademelerinde kadınların erkeklere oranla daha dezavantajlı konumda olduğu görülmektedir. Kadınların her kademede erkeklere oranla daha az eğitim görmesinin nedenleri arasında geçmiş dönemlerde özellikle Güneydoğu Anadolu bölgesinde kı çocuklarının okutul(ma)masına dair takınılan geleneksel tavır büyük rol oynamaktadır. Bunun yanı sıra geçmiş yıllarda Batman ve kırsalında, eğitim kurumlarındaki fiziki yetersizlikler (okul sayısının az oluşu, birleştirilmiş sınıflarda eğitim vb. gibi) öğretmen ihtiyacının istendik düzeyde karşılanamaması vb. gibi daha birçok nedenden dolayı okullaşma oranı düşük iken, eğitime son yıllarda yapılan yatırımlar sonrası kız çocuklarının okullaşma oranı giderek artmakta, kız ve erkek 
çocuklarının okullaşma oranları arasındaki makas hızla daralmaktadır (Türk, 2016, s.107).

$\mathrm{Bu}$ verilerden, ebeveynlerin eğitim düzeyi ile çocukların çalışması arasında ilişki bulunduğuna da ulaşılmaktadır. Çocukların bilinçli bir şekilde yetiştirilmemesi, sokakta çalışmalarından kaynaklı tehlike ve risklere dair öngörü eksikliği, ebeveynlerin eğitim düzeyinin yetersizliğinden kaynaklanmaktadır.

Çocukların sokakta çalışmalarına neden olan bir diğer husus aile bireylerinin düzenli bir işinin olup olmamasıdır. Örneklem kapsamında görüşülen sokakta çalış(tırıl)an çocukların annelerinin büyük bir oranı (\% 93,8) ev hanımıdır. Babalarının işlerinde ise durum pek farklı görülmemektedir. Araştırma bulgularına göre sokakta çalış(tırıl)an çocukların babalarının büyük bir kısmı herhangi bir iş güvencesi olmayan, özel bir beceri gerektirmeyen "enformel sektör" içerisinde yer almaktadır.

Tablo 3: Katılımcı Babalarının Mesleki Durumu

\begin{tabular}{llllll}
\hline Değişken & Frekans & $\begin{array}{l}\text { Yüzde } \\
\mathbf{( \% )}\end{array}$ & Değişken & Frekans & $\begin{array}{l}\text { Yüzde } \\
\mathbf{( \% )}\end{array}$ \\
\hline Tüccar & 1 & 0,8 & Karton toplayıc1 & 1 & 0,8 \\
Kapıcı & 1 & 0,8 & Kaynakçı & 1 & 0,8 \\
Ayakkabıc1 & 1 & 0,8 & Kebapçı & 1 & 0,8 \\
Balıkçı & 3 & 2,3 & Lokantacı & 2 & 1,6 \\
Bekçi & 2 & 1,6 & Manav & 3 & 2,3 \\
Boyacı & 1 & 0,8 & Memur & 3 & 2,3 \\
Büfeci & 1 & 0,8 & Mermer ustası & 1 & 0,8 \\
Çayc1 & 4 & 3,1 & Nakliyatçı & 2 & 1,6 \\
Çiftçi & 4 & 3,1 & Oyuncakçı & 1 & 0,8 \\
Çorapçı & 1 & 0,8 & Pazarcı & 1 & 0,8 \\
Demirci & 1 & 0,8 & Saman satıcısı & 3 & 2,3 \\
El arabacı & 1 & 0,8 & Serbest & 11 & 8,5 \\
Emekli & 1 & 0,8 & Seyyar & 10 & 7,8 \\
Esnaf & 5 & 3,9 & Şoför & 9 & 7,0 \\
Geçici işçi & 5 & 3,9 & Tamirci & 1 & 0,8 \\
Güvenlikçi & 2 & 1,6 & Tpao geçici işçi & 1 & 0,8 \\
İnşaatçı & 13 & 10,1 & Diğer & 31 & 24,1 \\
& & & Toplam & $\mathbf{1 2 9}$ & $\mathbf{1 0 0}$ \\
\hline
\end{tabular}


Babalarının iş kolları dağılımına bakıldığında \% 75,9'unun ücretli bir işte çalıştı̆̆ görülmektedir. Ancak bu ücretli işlerin neredeyse tamamına yakını "marjinal sektör" içerisinde yer alan (boyacı, çorapçı, el arabacı, karton toplayıc1, pazarcı ...vb.) işlerden ibarettir. Düzenli gelir getiren bir işte çalışan baba sayısı ise oldukça düşüktür. Katılımcıların \%22,5'nin babası işsiz ve 1 katılımcının babası mahkum diğerinin babası ise vefat etmiştir.

Hızlı göçler sonucu, kentlerde belirli istihdam özelliklerine sahip bir sektör anlayışının ortaya çıkmasını sağlamıştır. Bu sektör, kalkınma yazınında "marjinal sektör" veya "enformel sektör" diye adlandırılmaktadır (Tekeli, 1977, s.45). Bu sektör hızlı bir kentleşme sürecinin yaşandığı Batman'da da hayata tutunmak için birçok bireye geçici, güvencesiz ve düşük gelirli istihdam sağlayan alandır. Çocukları da sokakta çalışmaya sevk eden en önemli nedenlerden birisi de hiç kuşku yok ki, ebeveynlerinin sabit bir gelire sahip ol(a)maması veya sosyal güvence noktasında yaşadıkları sıkıntılardır. Sokakta çalış(tırıl)an çocukların \% 22,5'inin babası işsiz ve geri kalan iki çocuktan birinin babası ölmüş biri ise mahkûmdur. $\mathrm{Bu}$ veriler bir arada değerlendirildiğinde, sokakta çalış(tırıl)an çocukların büyük çoğunluğunun düzenli bir geliri olmayan yoksul ailelerin üyesi olduğu, bu durumun çocukları sokağa iten temel neden olduğu söylenebilir.

Tablo 4: Katılımcıların İkamet Ettiği Mahalle

\begin{tabular}{llllll}
\hline $\begin{array}{l}\text { Oturduğu } \\
\text { Mahalle }\end{array}$ & Frekans & Yüzde (\%) & $\begin{array}{l}\text { Oturduğu } \\
\text { Mahalle }\end{array}$ & Frekans & $\begin{array}{l}\text { Yüzde } \\
\text { (\%) }\end{array}$ \\
\hline 19 Mayıs & & & Hürriyet & 8 & 6,2 \\
Aydınlıkevler & 5 & 3,9 & Iluh & 4 & 3,1 \\
Bağlar & 5 & 4,7 & Karşıyaka & 8 & 6,2 \\
Bahçelievler & 1 & 3,9 & Kismet & 1 & 0,8 \\
Bayındır & 1 & 0,8 & Kültür & 3 & 2,3 \\
Cudi & 8 & 0,8 & Petrolkent & 13 & 10,1 \\
Cumhuriyet & 2 & 6,2 & Pınarbaş1 & 1 & 0,8 \\
Çamlıca & 14 & 1,6 & Sağlık & 5 & 3,9 \\
Çamlıtepe & 3 & 10,9 & Seyitler & 3 & 2,3 \\
Çarş1 & 2 & 2,3 & Şirinevler & 1 & 0,8 \\
Fatih & 2 & 1,6 & Yenimahalle & 5 & 3,9 \\
Gap & 3 & 1,6 & Yenişehir & 2 & 1,6 \\
Hilal & 3,3 & Yeşiltepe & 7 & 5,4 \\
Huzur & 7 & 2,3 & Cevapsiz & 6 & 4,7 \\
& & 5,4 & Toplam & $\mathbf{1 2 9}$ & $\mathbf{1 0 0}$ \\
\hline
\end{tabular}


İçgöçlerin ${ }^{4}$ etkisiyle hızlı bir kentleşme süreci yaşayan Batman'da, sokakta çalış(tırıl)an çocukların \%82,2'si il merkezlerinde, \%13,2'si ilçelerde ve \%4,7'si ise köylerde doğmuştur. Çocukların ikamet ettikleri mahallelere bakıldığında; Çamlıca, Güneykent, Petrolkent, Hürriyet, Karşıyaka, İluh gibi mahallelerin ön plana çıtığı görülmektedir. Bu mahalleler gecekondulaşmanın ilk örneklerini oluşturmaktadır. Kuzey yönünde kurulan mahallelere (Belde, Gültepe, Tılmerç gibi) göre güney yönündeki bu mahalleler sosyo-ekonomik göstergeler noktasında daha düşük düzeyde (Türk, 2016, s.123) ve kentsel yoksulluk görünürlügünün en fazla olduğu mahallelerdir.

$\mathrm{Bu}$ mahallelerde yaşayan bireylerin büyük bir kısmı, asgari geçimini sağlayabilecek kaynaklara ulaşmada güçlük çeken -büyük oranda işsizlikle mücadele içinde ya da marjinal sektörde geçim olanakları sağlayan- sosyal güvenceleri yetersiz ve kentle bütünleşme noktasında sorun yaşayanlardan oluşmaktadır. Sokakta çalış(tırıl)an çocukların büyük bir kısmının bu mahallelerde oturuyor olması da tesadüfi değildir. Ebeveynleri ekonomik sıkıntılar yaşayan çocuklar, aynı durumu büyük ölçüde yaşamakta, kentsel yoksulluğu aileleriyle birlikte deneyimlemektedirler. Bu nedenle aile bütçesine katkı sağlamak adına kendi rızaları (\% 82,2), aile yönlendirmesi veya özendirmesiyle $(\% 17,2)$ ya da arkadaş etkisiyle $(\% 0,8)$ sokakta çalışmaya başlamaktadırlar.

Tablo 5: Katılımcıların Hane Halkı Sayısı

\begin{tabular}{lll}
\hline Değişken & Frekans & Yüzde (\%) \\
\hline $1-5$ & 14 & 10,9 \\
$6-10$ & 95 & 73,6 \\
11 ve üzeri & 20 & 15,5 \\
Toplam & $\mathbf{1 2 9}$ & $\mathbf{1 0 0}$ \\
\hline
\end{tabular}

Araştırma bulgularına göre, sokakta çalış(tırıl)an çocukların \%73,6'sının ailelerindeki kişi sayısı 6 ve 10 kişi arasında olduğu tespit edilmiştir. Bu veriler sokakta çalış(tırıl)an çocukların çok çocuklu ailelere mensup bireyler olduğunu göstermektedir.

\footnotetext{
${ }^{4}$ Araştırmanın yapıldığı kent merkezi her ne kadar içgöçlerle oluşmuş olsa da, örneklemin çocuklardan oluşmasından dolayı ebeveynlerinin nerelerden ve ne zaman bu kente gö̧̈ ettiklerine dair sağllklı bilgilere ulaşılamamış olup, bu gerekçeyle net rakamlar paylaşılamamıştır.
} 
Tablo 6: Katılımcıların Ailelerindeki Toplam Çalışan Sayısı

\begin{tabular}{lll}
\hline Değişken & Frekans & Yüzde (\%) \\
\hline 1 & 15 & 11,6 \\
2 & 44 & 34,1 \\
3 & 36 & 27,9 \\
4 & 22 & 17,1 \\
5 & 12 & 9,3 \\
Toplam & $\mathbf{1 2 9}$ & $\mathbf{1 0 0}$ \\
\hline
\end{tabular}

Araştırma bulgularına göre, sokakta çalış(tırıl)an çocukların hanelerindeki çalışan sayısına bakıldığında katılımcılardan \%88,4'ünün hanesinde iki ve daha fazla birey çalışmaktadır.

$\mathrm{Bu}$ verilerden hareketle şunlar söylenebilir: Öncelikle ailedeki kişi sayısının fazla olması ve ebeveynlerin büyük bir kısmının nitelik gerektirmeyen ve düzensiz işlerde çalışıyor olması, bu ailelere mensup çocukların sokakta çalışmalarının en temel gerekçelerindendir. Böylesi ailelerde aile bütçesine katkı sağlayabilmek için ailenin hemen her bireyi çalışma zorunluluğu hissedebilmektedir. Çünkü hanedeki toplam üye sayısı arttıkça temel ihtiyaç listesi biraz daha kabarmakta ve işgücü arzı artmaktadır. Aile bütçesine çocuk yaşlarda katkı sağlamak bir nevi bu çocuklar için mecburiyet haline gelebilmektedir.

Tablo 7: Katılımcı Hanelerinin Ortalama Aylık Geliri

\begin{tabular}{llll}
\hline Değişken & Frekans & Yüzde (\%) & Geçerli Yüzde (\%) \\
\hline 750 lira ve altı & 39 & 30,2 & 31,7 \\
$751-1500$ & 65 & 50,4 & 52,8 \\
$1501-2500$ & 9 & 7,0 & 7,3 \\
$2501-3000$ & 8 & 6,2 & 6,5 \\
3001 ve üstü & 2 & 1,6 & 1,6 \\
Cevapsiz & 6 & 4,7 & - \\
Toplam & $\mathbf{1 2 9}$ & $\mathbf{1 0 0}$ & $\mathbf{1 0 0}$ \\
\hline
\end{tabular}

Batman'da çocukların sokakta çalış(tırıl)ması ile ailenin aylık toplam geliri arasında doğrudan bir ilişki olduğu söylenebilir. Aylık gelir durumu sorulurken aile içinde yaşayan tüm bireylerin ne kadar kazanç sağladığına ilişkin bilgilere ulaşılmaya çalışılmıştır. Nitekim ailelerin aylık toplam gelirlerine bakıldığında, yarısından fazlasının (\% 52,8) 751 ile 1500 lira arasında bir gelire sahip olduğu, geri kalan \% 31,7'sinin ise ortalama aylık gelirlerinin 750 lira ve altında olduğu beyan edilmiştir. 
Ancak burada dikkat edilmesi gereken husus; örneklemin çocuklardan oluşmasından dolayı hane gelirine ilişkin net bilgilere ulaşılamamış olma riskidir.

Açlık ve yoksulluk sınırlarına dair yapılan çalışmalara bakıldığında Memur-Sen Konfederasyonu'nun açlık-yoksulluk araştırmasında, 2019 Mayıs ayı için 4 kişilik bir ailenin sağlıklı,dengeli ve yeterli beslenebilmesi için yapması gereken aylık gıda harcaması tutarı (açlık sinırı) 2390 lira, Gıda harcaması ile birlikte giyim, konut (kira, elektrik, $\mathrm{su}$, yakıt), ulaşım, eğitim, sağlık ve benzeri ihtiyaçlar için yapılması zorunlu diğer aylık harcamalarının toplam tutarı ise (yoksulluk sınırı) 6532 lira olarak tespit edilmiştir (Memursen, 2019). Türk-İş ise aynı dönemde açlık sınırını 2123 lira, yoksulluk sınırını ise 6918 lira olarak tespit etmiştir (Türk-İs, 2019). Konfederasyonların yaptığı araştırmalarla bu araştırma verileri bir arada değerlendirildiğinde, sokakta çalış(tırıl)an çocukların çoğunluğunun açlık sınırı altında bir gelire sahip olduğu görülmektedir. Türk (2016, ss. 118-119) tarafından daha önce yapılan bir araştırmada, Batman'da yaşayan bireylerin büyük bir çoğunluğu yoksulluk sınırındayken, yarısından fazlasının açlık sınırının altında yaşadığı görülmektedir. Ancak toplumumuzda kazancını net rakamlarla ifade etmeme noktasındaki yaygın tutum ve örneklemin çocuklardan oluşması, aile gelirine ilişkin sağlıklı verilere ulaşmayı engellemektedir.

Araştırma bulgularına göre, katılımcıların oturdukları evlerin çoğu düşük standartlarda gecekondu diye ifade edilen, bahçeli ya da bahçesiz müstakil evler ile sonradan eklenen katlarla apartmanlara dönüşen konutlardan oluşmaktadır. Çalışma verilerine göre, 2-3 katlı dairelerde $(\% 43,4)$ ve müstakil evlerde $(\% 41,9)$ oturanlar ağırlıktadır.

Oturulan konutlarda oda sayısının fazlalığı ve evlerin büyüklüğü dikkat çekmektedir. Bu durum sosyo- kültürel unsurlara dayandırarak açklanabilir. \% 26,4'ü iki odalı, \% 46,5'i üç odalı ve \% 17,8'i ise dört odalı bir evde oturmaktadır. Katılımcıların \% 49,6'sı kiralık bir konutta oturduklarını beyan etmektedir. Kirada oturanların \% 48,4'ü 100- 250 lira arasında ve \% 43,8'i ise 250 ile 500 lira arasında bir ücret ödediklerini ifade etmektedir. Sosyal güvence durumuna bakıldığında ise \% 71,1'inin genel sağlık sigortasından yararlandıkları görülmektedir. Bu durum çoğu çocuğun ebeveynlerinin güvencesiz işlerle geçimlerini sağladıklarının bir göstergesi olabilir. Nihai olarak, sokakta çalış(tırıl)an 
çocukların büyük çoğunluğu, sosyo-ekonomik düzeyi düşük, yoksulluğun egemen olduğu, kentin periferisi konumunda bulunan ve gecekondu diye tanımlanan $^{5}$ mahallelerde ikamet ettikleri görülmektedir.

\section{Sokakta Çalışma Nedenleri ve Karşılaşılan Sorunlar}

Batman'da sokakta çalış(tırıl)ma nedenleri bakımından, hızlı bir kentleşme süreci, zorunlu göçlerin de etkisiyle artan kentsel yoksulluk ve ailelerin çocuklarını sokakta çalıştırmalarından doğan istismar ön plana çıkmaktadır. Kentte artan ihtiyaçlar sonrası çocukların işgücüne dâhil edilme "mecburiyeti" ya da "istismarı" göçlerden teşekkül bir kentte doğan bu çocukların çalışma nedenleriyle örtüşmektedir.

Tablo 8: Katılımcıların Sokakta Çalışma Neden(ler)i

\begin{tabular}{lll}
\hline Değişken & Frekans & Yüzde (\%) \\
\hline Aileye katkı & 65 & 50,4 \\
Aile borcu ödeme & 11 & 8,5 \\
Okul harçlı̆̆ı karşılama & 38 & 29,5 \\
Okumaya isteksizlik & 3 & 2,3 \\
Ailedekilerin çalış(a)maması & 2 & 1,6 \\
Hayat tecrübesi edinme & 3 & 2,3 \\
Diğer & 7 & 5,4 \\
Toplam & $\mathbf{1 2 9}$ & $\mathbf{1 0 0}$ \\
\hline
\end{tabular}

Yoksul ailelerde tek başına ebeveynlerin çalışması aile geçimini sağlamaya yetmediğinden, çocuklarının kazancına da ihtiyaç duyulabilmektedir. Buna göre, sokakta çalış(tırıl)an çocukların çalışma nedenlerine bakıldığında büyük oranda ekonomik kaygılar (aileye katkı, aile borcunun ödenmesi gibi) temel motivasyon kaynağını oluşturmaktadır. Benzer bir neden ise ailedeki gelir güvencesizliğidir. Gelir güvencesizliğinden dolayı aileye yük olmak istemeyen çocuklar, okul harçlığını kazanabilmek $(\% 29,5)$ için sokaklarda çalıştıklarını ifade etmektedir.

\footnotetext{
${ }^{5}$ Bu mahalleler aynı zamanda kentin yoksulluk haritasını oluşturan yerleşim yerleridir. Konu ile ilgili detaylı bilgiler için araştırmacının "Hızl Kentleşme Sürecinin Toplumsal Yapıya Etkileri: Batman Örneği" adlı çalışmasına bakılabilir.
} 
Katılımclara iradi mi yoksa başkalarının yönlendirmesi veya özendirmesiyle mi çalıştıklarına dair sorulan soruya, aile bütçesine katkı sağlamak adına kendi rızasıyla (\% 82,2) çalıştığını söyleyen büyük çoğunluğun yanında, aile yönlendirmesi veya özendirmesiyle $(\% 17,2)$ ya da arkadaş etkisiyle (\% 0,8) sokakta çalıştığını söyleyen çocuklar da bulunmaktadır.

İster iradi ister de bir başkasının yönlendirmesi veya özendirmesiyle olsun, uluslararası bağlayıcı kararlar çerçevesinde bu durum hukuken bir suç olarak tanımlanmaktadır. Ancak bu durum, çocukların aile bütçesine katkı sağlama amacıyla çalışmak istedikleri gerçeğinin de göz ardı edilmeden bağlayıcı kararlarla bir arada değerlendirilmesi gereken çok boyutlu bir konudur.

Sokakta çalış(tırıl)an çocuklar açısından önemli olan bir diğer durum ise çalışma yaşamında bulunan çocukların okula devam edip etmedikleri hususudur. Uluslararası Çalışma Örgütü'nün (ILO) 138 Sayılı Kararı'na göre, iş hayatına başlama için minimum yaş konusunda zorunlu okul eğitiminin tamamlandığı yaştan aşağı olmayacağı hükmüne bağlanmiştır.

Boidin'in (1995, s.18) belirttiği gibi, özellikle kentsel alanlarda çalışan çocuk, daha baştan onu çalışmaya zorlayan ekonomik ve ailesel yönlendirme ile öğrenme isteği ve gereksinim arasında ikilem yaşamaktadır. Böylece zaman içinde bu dayanılmaz durum, çocuğun tamamen okulu terk etmesine kadar uzanabilmektedir (akt. Altuntaş, 2014, s.47). Para kazanmanın ve aileye destek olmanın verdiği mutluluk, çocuklarda okul ile sokak arasında gitgellere neden olabilmektedir. Her ne kadar katılımciların büyük bir bölümü okullarına devam ediyor olsalar da, sokakta geçirilen süre uzadıkça, çocukların ileriki yıllarda okula devam edip etmeyecekleri hususu önemli bir sorun olarak karşımızdadır.

Sokakta çalış(tırıl)an çocukların iş türüne bakıldığında, \%16,3 ile mevsime göre değişen iş türlerinin ( kağıt mendil, yeşilnohut vb.) ön planda olduğu görülmektedir. Çocuklar, kışın kağıt mendil, yazın ise yöreye has yeşil nohut satışı yaptıklarını ifade etmiştir. Bu iş türünün yanında en çok karton toplayıcılığı yapılmaktadır. Ayrıca toptancılardan tüketiciler tarafından alınan malzemelerin taşınması için el arabacılığı ya 
da bir diğer adıyla hamal arabacılığ $1^{6}$ (Parin, 2012, s.451) en çok yapılan iş türlerindendir.

Tablo 9: Katılımcıların İş Türleri

\begin{tabular}{llllll}
\hline İş Adı & Frekans & $\begin{array}{l}\text { Yüzde } \\
\mathbf{( \% )}\end{array}$ & İş Ad1 & Frekans & $\begin{array}{l}\text { Yüzde } \\
\mathbf{( \% )}\end{array}$ \\
\hline $\begin{array}{l}\text { Ayakabı } \\
\text { Boyacısı }\end{array}$ & 8 & 6,2 & $\begin{array}{l}\text { Mevsimlik işler } \\
\text { (mendil,yeşil nohut vb.) }\end{array}$ & 21 & 16,3 \\
\hline Cam silici & 4 & 3,1 & Misırc1 & 3 & 2,3 \\
\hline Ciğer satıcıS1 & 2 & 1,6 & Pazarcı & 2 & 1,6 \\
\hline Çekirdekçi & 10 & 7,8 & Sigara satıcısı & 6 & 4,7 \\
\hline Çorap satıcısı & 4 & 3,1 & Simitçi & 9 & 7,0 \\
\hline El arabacı & 15 & 11,6 & Su satıcısı & 11 & 8,5 \\
\hline Hurdacı & 2 & 1,6 & Tartıc1 & 7 & 5,4 \\
\hline $\begin{array}{l}\text { Karton } \\
\text { toplayıcı }\end{array}$ & 19 & 14,7 & $\begin{array}{l}\text { Diğer } \\
\text { (çakmak,aksesuar vb.) }\end{array}$ & 6 & 4,8 \\
\hline & & Toplam & $\mathbf{1 2 9}$ & $\mathbf{1 0 0}$ \\
\hline
\end{tabular}

Ayrıca su satıcılı̆̆ı, simitçilik, boyacılık, karpuz çekirdeği satıcılığ gibi iş türleri de sokakta çalış(tırıl)an çocukların en çok rağbet ettikleri işlerdir. Sokakta çalış(tırıl)an çocukların yaptıkları işler büyük oranda beceri gerektirmemektedir. Fiziksel çaba gerektiren görece daha ağır işler, yaşı ilerlemiş çocuklar tarafından yapılmaktadır.

Tüm bu iş türleri bir arada değerlendirildiğinde, işlerin niteliği tehlikeli gibi görünmezse de, çocukların sokakta çalışmak durumunda olmaları başlı başına tehlike ve riskleri içinde barındıran bir gerçektir.

Tablo 10: Katılımcıların Çalışmaya Başlama Yaşı

\begin{tabular}{lll}
\hline Değişken & Frekans & Yüzde (\%) \\
\hline 9 yaş ve altı & 42 & 32,6 \\
$10-12$ & 61 & 47,3 \\
$13-15$ & 26 & 20,2 \\
Toplam & $\mathbf{1 2 9}$ & $\mathbf{1 0 0}$ \\
\hline
\end{tabular}

Uluslararası Çalışma Örgütü'nün (ILO) 138 Sayılı Kararı, iş hayatına başlama için minimum yaş konusunda zorunlu okul eğitiminin

${ }^{6} V a n ' d a$ enformel bir iş kolu olan hamal arabacılık için Parin (2012) tarafindan yapılan "Kent ve Çocuk: Nakliyecilik/Hamallık Yapan Çocuklar Üzerine Bir Araştırma" adlı çalışmada konuya ilişkin detaylı bilgilere ulaşılabilir. 
tamamlandığı yaştan aşağı olmayacağını hükmüne rağmen, Tablo'daki verilere bakıldığında sokakta çalış(tırıl)an çocukların üçte biri (\% 32,6) 9 yaş ve altında çalışmaya başladığını ifade etmektedir. Çalışmaya başlama yaşı itibariyle en yüksek oran \% 47,3 ile 10-12 yaş aralığındaki çocuklardan oluşmaktadır. Son olarak 13-15 yaş aralığındaki çocukların oranı ise $\% 20,2^{\prime}$ dir.

Erken yaşta çalışmaya başlamanın çocuğun bedensel ve ruhsal gelişimini olumsuz etkileme ihtimali, bir takım düzenlemeleri zorunlu kılmakta ve çalışmaya başlama yaşına ilişkin pek çok ülkede hukuki düzenlemeler yapılmaktadır. Ancak gerek ülkemizde gerekse dünyanın birçok yerinde medya aracılığıyla aktarılan görüntülere bakıldığında, Uluslararası Çalışma Örgütü (ILO) ve diğer kuruluşların aldıkları kararların altına atılan imzalar, taraf ülkeleri bağlayıcı olsa da bu kararların sahada çok fazla uygulanamadığı gözlemlenebilir.

Tablo 11: Katılımcıların Günlük Ortalama Kazancı

\begin{tabular}{lll}
\hline Değişken & Frekans & Yüzde (\%) \\
\hline 10 lira ve altı & 41 & 31,8 \\
$11-20$ & 59 & 45,7 \\
$21-30$ & 19 & 14,7 \\
$31-40$ & 5 & 3,9 \\
$41-50$ & 3 & 2,3 \\
$51-60$ & 1 & 0,8 \\
61 ve üstü & 1 & 0,8 \\
Toplam & $\mathbf{1 2 9}$ & $\mathbf{1 0 0}$ \\
\hline
\end{tabular}

Yukarıda da ifade edildiği üzere katılımcılar, aile bütçesine katkı sağlamak için, kendi rızaları (\% 82,2), aile yönlendirmesi veya özendirmesiyle $\left(\begin{array}{ll}\% & 17,2\end{array}\right)$ ya da arkadaş etkisiyle (\% 0,8$)$ sokakta çalışmaya başlamıştır. Bu çalışmada, sokakta çalış(tırıl)an çocukların \% 77,5 gibi büyük bir oranı günlük 20 lira ve altında bir kazanç elde ettiğini paylaşmıştır. Günlük 50 lira ve üzeri kazancı olanların oranı ise \% 1,6'dır. Bu verilerden de anlaşılacağı üzere zaten çalışmaları yasal olmayan bu çocukların çoğu gündelik yaşamlarının (okulda geçirilen süre dışında) büyük bir kısmını sokakta çalışarak (ortalama 5-6 saat) geçirdikleri halde elde ettikleri kazançlarının asgari ücretin altında ve düzensiz bir gelir olduğu görülmektedir. 
Tablo12: Katılımcıların Sokaktaki Kazancın Aileleriyle Paylaşımı Durumu

\begin{tabular}{lll}
\hline Değişken & Frekans & Yüzde (\%) \\
\hline Tamamını & & \\
Bir kısmını & 72 & 55,8 \\
Şahsi birikim & 42 & 32,6 \\
Diğer & 11 & 8,5 \\
Toplam & 4 & 3,1 \\
\hline
\end{tabular}

Sokakta çalış(tırıl)an çocuklar, aile bütçesine katkı sağlamak üzere kazançlarının büyük bölümünü ebeveynleriyle paylaşmaktadır. Buna göre kazancının tamamını ebeveynleriyle paylaşan çocukların oranı \% 55,8'dir. Kazancinın bir kısmını ebeveynleri bir kısmını ise bireysel ihtiyaçları için kullanan çocukların oranı ise \% 32,6'dır. Bu oranlara bakıldığında sokakta çalış(tırıl)an çocukların büyük bir kısmının kazançlarını ebeveynleriyle paylaşarak bu şekilde aile bütçesine katkı sağlamaktadır.

Tablo 13: Katılımcıların Sokakta Çalışma Memnuniyeti

\begin{tabular}{lll}
\hline Değişken & Frekans & Yüzde (\%) \\
\hline Evet & 96 & 74,4 \\
Hayır & 33 & 25,6 \\
Toplam & $\mathbf{1 2 9}$ & $\mathbf{1 0 0}$ \\
\hline
\end{tabular}

Araştırmada çocukların sokakta çalışma memnuniyetiyle ilgili görüşleri de öğrenilmeye çalışılmıştır. Buna göre, Batman'da sokakta çalış(tırıl)an çocukların \% 74,4'ü sokakta çalışmaktan memnun olduklarını ifade etmişlerdir. Aile bütçesine katkı sağlıyor olmanın verdiği mutluluk sokakta çalışma memnuniyetinin en önemli gerekçesini oluşturmaktadır. Batman'da sokakta çalış(tırıl)an çocukların \% 25,6'sı ise sokakta çalışmaktan memnun olmadıklarını ifade etmişlerdir.

$\mathrm{Bu}$ çalışmanın odak noktalarından biri de çocukların sokakta karşılaştıkları tehlike ve risklere değinmektir. Buna göre, katılımcılardan sokakta çalışmaktan memnun olmayanların \% 54,5'i memnun olmama gerekçesi olarak, sokakta var olan tehlike ve riskleri (suça bulaşma,istismara uğrama vb gibi nedenler) belirtmektedir.

Çocuklar, sokakta çalışmalarından dolayı suça maruz kalabilmekte ve suç eğilimi geliştirebilmektedir. Bu çocuklar, bir takım kişi, çete ve 
gruplar tarafından kapkaç ve gasp gibi işlerde de kullanılabilmektedir (Güngör, 2008, ss.28-29).

Tablo 14: Sokakta Çalışmaktan Memnun Olmama Nedeni?

\begin{tabular}{lll}
\hline Değişken & Frekans & Yüzde (\%) \\
\hline Maddi getirisinin az olması & 10 & 30,3 \\
\hline İnsanların hor görüyor olması & 5 & 15,2 \\
\hline $\begin{array}{l}\text { Tehlikeli ve riskli olması (suça bulaşma,istismara uğrama, } \\
\text { madde bağımlılığı gibi nedenler) }\end{array}$ & 18 & 54,5 \\
\hline Toplam & $\mathbf{3 3}$ & $\mathbf{1 0 0}$ \\
\hline
\end{tabular}

Çocukların yaptığı işlerin niteliğine bakıldığında, tehlikeli olmayan işler gibi görülse de, sokakta geçirdikleri süre uzadıkça yeni ilişki ağları içine girdikleri, başta sigara olmak üzere bir takım uçucu madde bağımlılıklarına doğru sürüklenebildikleri, akranlarının etkisiyle suça bulaşma ve istismara uğrama ihtimalleriyle karşı karşıya olduklarını beyan etmişlerdir. Sokakta çalış(tırıl)an çocukları bekleyen bu tehlikelerin her biri tek tek irdelenmesi gereken konulardır.

Sokakta çalışmaktan memnun olmayan çocukların \%30,3'lük kısmı ise getirinin az olmasını gerekçe olarak göstermektedir. Getirilerinin az olduğu bazı zamanlarda, çocuklar satıcı mıyoksa dilenci mi olduklarını karıştırabilmekte, yüklendikleri ağır sorumluluk gereği dilencilerle benzer davranış kalıpları sergileyebilmektedirler. Bu risk dahi sokakta çalış(tırıl)manın hangi boyutlara evrilebileceğinin açık göstergelerindendir. Son olarak bir sosyal dişlanma biçimi olan hor görülme hissi de çocukların sokaklarda çalışma memnuniyetsizliklerinden birini oluşturmaktadır.

\section{Sonuç ve Öneriler}

Batman'da "Sokakta çalış(tırıl)an çocuklar"ın neredeyse tamamı ebeveynleriyle bir arada yaşayan ve akşam evlerine dönen çocuklardır. Ancak zorunlu eğitim çağında olan bu çocuklar, sokaklarda geçirdikleri zaman uzayıp sokağın karanlık yönleriyle hemhal oldukça, sokağı mesken edinmiş, çoğunlukla madde bağımlısı olan ve aile desteği olmayan "sokağın çocukları" olmaya aday birer birey olma riski taşımaktadır. Bugün maalesef "bir zamanların güvenli sokağı, artık 
kontrolsüz ve zararlı güç odaklarının kontrolü altına girmiştir. Eskiden, mahalle ortamı sosyal hayatın canlı ve güvenli bir mekânı iken bugün tehlikeli ve korkutucu bir niteliğe bürünmüştür" (Şener ve Serdar, 2015, s.116). Eğitimin hangi kademesinde olursa olsun, sokakta çalış(tırıl)an çocukların büyük bir kısmının okula devam ediyor olması büyük bir önem arz etmektedir. Ancak sokakta geçirilen süre arttıkça ve maddi kazanç elde etmenin verdiği hazzın etkisiyle çocukların okulu önemsememe ya da terk etme eğilimleri artabilmektedir.

Sokakta çocukları bekleyen tüm risklere rağmen, çocukların büyük bir kısmı $(\% 74,4)$ sokakta çalış(tırıl)mayı olumlayan bir tavır sergilemektedir. Aile bütçesine katkı sağlayarak yoksulluk sarmalından kurtuluşta bir halka olduklarına olan inanç, yaptıkları işleri bir övünç kaynağı olarak görmelerini sağlamaktadır. Erken yaşlarda çalışma hayatını deneyimleyen bu çocuklar için şartlar değişmediği sürece, yoksulluk, kısır döngüye dönüş(ebil)mektedir. Bu sonuçlar araştırmanın temel varsayımını da doğrulamaktadır.

Sokaktaki çocuklar olgusunu salt ekonomik ve/veya kültürel değişkenlerle açıklamak olanaksızdır. Bu olgu birey, aile, grup ve topluluk/toplum düzeyindeki faktörlerin bir bileşenidir. Bu nedenle çözüm stratejisi kapsamlı ve çok boyutlu olmak zorundadır (Acar, 2010, s.8). Ayrıca bu olgudan kaynaklanan sorunların çözümüne katk1 sağlaması amacıyla yapılacak çalışmaların da çocuk eksenli olmasından önce ebeveyn eksenli olması daha büyük fayda sağlayabilir (Alacan, 2010, s.144).

Çalışma verilerinden hareketle sokakta çalış(tırıl)an çocukların ailelerinin sosyo-ekonomik durumu oldukça düşüktür. Sosyo-ekonomik durumu düşük olan bu ailelerin çocuk emeği noktasında fazla hassasiyet göstermedikleri görülmektedir. Ancak gittikçe kronikleşmeye başlayan bu sorunun çözümü için aileleri suçlayıcı bir yaklaşım yerine, mevcut sorunların tespiti ve bu ailelerin ekonomik ve sosyal bakımdan kentle bütünleşme olanaklarının sağlanması gerekmektedir. Sokaktan çekilmeye çalışılan bu çocuklara bakmakla yükümlü olan ebeveynlerine istihdam olanakları yaratılarak formel sektörlerde çalışma imkanları geliş̧irilmelidir. "Çocuğun yüksek yararı" bağlamında "en az zararlı olan çözüm" yolları aranmalıdır. Yani çocuğu sokaklardan çekerken, 
çocuk ve çocuğun katkı sağladığı ailenin daha da yoksullaşmayacağı bir denklem oluşturulabilmelidir.

Unutulmamalıdır ki, akranlarıyla oyunlar oynayarak sosyalleşme sürecinde olan bu çocuklar, çok erken yaşlarda sokakları mesken tutmaktadır. Hayatın omuzlarına yüklediği ağır yük onları yaşından daha büyükmüş gibi bir hisse kapılmaya ve ona göre roller üstlenmeye zorlayabilmektedir. Her ne kadar geleneksel anlamda bir takım kültürel kodlarla, aile bireylerinin bütçeye birlikte katkı sunmaları olumlu karşılanıp çocuklar için sokakta çalışmak bir hayat tecrübesi olarak adlandırılsa da çocuklar bu deneyimleme sürecinde her türlü tehlikeyi içinde barındıran sokaklarda muhtemel suç örgütlerine dahil olma riski ile karşı karşıya kalmaktadır. Bu açıdan başta aile ilişkilerindeki süreklilik, bir takım kültürel kodların değişimi ve kurumlar düzeyinde çocukların korunmasına yönelik uluslararası sözleşmelerin uygulanmasıyla beraber bu riskler azaltılabilir. Son dönemlerde uygulanan kamu politikalarıyla sorunun çözümüne katkı sağlanmak istenmesine rağmen henüz istendik bir düzeye gelinememesinin üzerinde ehemmiyetle durulması gerekmektedir. Sokakta çalış(tırıl)an çocuklar ancak bu perspektifle sokakları mesken tutmak yerine ev, okul ve akranlar üçgeninde sosyalleşme süreçlerini sağlıklı bir şekilde sürdürebilir. Sokakta çalış(tırıl)an çocuklar için belediye, halk eğitim, emniyet, Aile Sosyal Politikalar il müdürlükleri, İş-kur gibi kurumların eşgüdümüyle oluşturulabilecek proje/programlar dahilinde (teşvik mahiyetinde bir ücret verilerek) mesleki bilgilerle donatılabilecekleri alternatif çalışmalarla kalıcı çözümler üretilebilir.

Son olarak Batman'da henüz yeni olan sokakta çalış(tırıl)an çocuklar gerçeği karşısında ciddi önlemler alınmadığı takdirde, kentte henüz örneğine rastlanmayan sokak çocuğu veya sokak çocukları gerçeğiyle karşı karşıya kalınma riski gözden kaçırılmamalıdır. Bu sorumluluk başta sokakta çalış(tırıl)an çocukların aileleri olmak üzere kamu kurum/kuruluş temsilcileri ve bu kentte yaşayan her bireye aittir. Sokakta çalış(tırıl)an çocukların "sokağın çocukları" haline dönüşmemesi için çaba sarf edilmesi aynı zamanda toplumsal bir sorumluluktur. Bu sorumluluğun yerine getirilmemesi yeni sorunların doğuşuna sebebiyet vereceğinden, konunun üzerinde detaylı bir şekilde durulması gerekmektedir. 


\title{
EXTENDED ABSTRACT
}

\section{Children Working/Worked in The Street in Batman and Risk They Face}

\author{
Emrullah Türk \\ Batman University
}

The phenomenon of street children who work by force, one of the problems that are faced by many cities, including metropolitan centers primarily in Turkey. Some children who lack the support of their parents live or work on the streets for reasons such as migration and poverty. In general, such children, defined as child laborers and street children are often found in underdeveloped and developing countries where income distribution is unfair. However, the exact number of these children is not known.

Turkey, beginning from 1950s onwards, has witnessed a huge internal migration wave from rural to urban areas. After a certain point this migration exceed the absorption capacity of urban centers in terms of employment opportunities so urban poverty dramatically increased. Urban poverty has led to an increase in the number of workers working in the informal sector on the one hand and a rapid increase in the number of children working/worked on the streets. In Turkey's all cities, mainly in metropolitan centers, including, in justice in income distribution, regional disparities, which amounted to forced recruitment, such as increasing urban poverty for many reasons, in different views, and the rate has been transformed into a recurring frame. The fact that the children who working/worked on the streets is also part of this photo frame.

Batman is a city in which the number of children working/worked on the streets has increased and become a problem with the urbanization of the immigrants starting from the 1950s. Children working/worked on the streets in Batman generally work at different points in the city to contribute to the family budget. When the job preferences of the children are analyzed, it is seen that the jobs that change according to the season 
(gum, tissue paper, green chickpeas, etc.) and the local (sale of watermelon seed, wheelbarrow for the transportation of the materials purchased from wholesalers) come to the fore. In addition to these works, cardboard collecting is one of the most common. In addition, water sales, bagel, painting jobs are among the most popular jobs for children working/worked in the street.

Compared to child workers working in a fixed workplace, the risk that children working/worked on the streets do not have a fixed workplace may pose certain risks. For example; As the working time of the children increases in the streets, their ties with the family decrease, and the new relationship networks established in this process may expose children who work in the streets to a number of volatile and drug addictions, especially cigarettes. Such addictions can cause neurological and psychiatric effects as well as social problems in individuals. In addition, these children, who are vulnerable on a street or avenue, can commit violence or may be exposed to violence in a verbal discussion at any moment. The scenes in which children face drivers in physical violence in the traffic light environment are witnessed every day.

Regardless of the level of education, it is of great importance that most of the children who are working/worked in the streets attend school. However, as the time spent on the street increases and the pleasure of earning financial gain, children's tendency to ignore or drop out of the school may increase.

Despite all the risks awaiting children on the street, the majority of children $(74.4 \%)$ have a positive attitude towards working/worked on the streets. The belief that they are a hoop in the emancipation of poverty by contributing to the family budget enables them to see their work as a source of pride. As long as the conditions for these children who experience working life at an early age do not change, poverty can become a vicious circle. Therefore, these results confirm the assumption that "the main reason for working in the street during childhood is precarious work and the low income level of the family they belong to".

Based on the research data, the socio-economic status of the families of children who working/worked on the streets is quite low. It is seen that these families with low socio-economic status do not show much sensitivity in terms of child rights. However, in order to solve this prob- 
lem which is becoming increasingly chronic, it is necessary to identify the existing problems and to increase the economic and social opportunities of these families instead of accusing the families. Employment opportunities should be created for their parents who are caring for these children who are trying to get out of the street. In the context of "high advantage of the child", "the least harmful solution" should be sought. In other words, when drawing the child off the streets, an equation should be created in which the child and the family that the child contributes to will not become impoverished.

Although it is traditionally known as a cultural experience that family members contribute to the budget together and it is named as life experience that children work on the street, children face the risk of being involved in possible criminal organizations in the streets that contain all kinds of danger in this experience. In this respect, these risks can be reduced with the continuity of family relations, the change of certain cultural codes and the implementation of international conventions for the protection of children at institutional level. Although it is desirable to contribute to the solution of the problem with the public policies implemented recently, it has to be importantly emphasized that it has not reached a desired level yet. Children working/worked in the streets can only maintain their socialization processes in a triangle of houses, schools and peers instead of keeping the streets inhabited.

For children who work in the streets, permanent solutions can be produced by alternative works in which they can be equipped with professional information (by giving a fee in the form of incentives) within the projects / programs that can be established with the coordination of institutions such as Municipality, Public Education, Police Headquarter, Family and Social Policies Provincial Directorates and Employment agency.

Ultimately, the risk of these children becoming into street children increases over time if measures are not taken for children working on the streets that are rarely seen for now in Batman. This responsibility belongs to the authorities of public institutions, especially the families of children working/worked on the streets, and to every individual living in this city. It is also a social responsibility to make efforts to ensure that children working on the streets do not become "children of the street". 


\section{Kaynakça / References}

Acar, H. (Haz.) (2010),Sokakta yaşayan velveya çalıştırılan çocuklara yönelik hizmet modelinin ve il eylem planlarının değerlendirilmesi Raporu, SHÇEK Genel Müdürlüğü-UNICEF Türkiye, Ankara.

Adıgüzel, Y. (2016), Göç Sosyolojisi, 1. Baskı, İstanbul:Nobel Akademik Yayıncilik.

Alacahan, O. (2010), Çocuğunu sokakta çalıştıran ailelerin sosyoekonomik profili,tutum ve beklentileri. Sosyal Siyaset Konferansları, $59,133-147$.

Altuntaş, B. (2014), Mendile, simite, boyaya, çöpe... Ankara sokaklarında çalş̧an çocuklar, 2. Baskı,İstanbul: İletişim Yayınları.

Atauz, S. (1998). Dünya kentlerinin yeni olgusu: Sokak çocukları, Birikim Dergisi, 116, 68-78.

Bilgin, R. (2012). Sokakta çalış(tırıl)an çocukları bekleyen risk ve tehlikeler: Diyarbakır örneği. ZKÜ Sosyal Bilimler Dergisi, 8(15), 7996.

Çağlayan, S. (2006). Göç kuramları göç ve göçmen ilişkisi. Muğla Üniversitesi Sosyal Bilimler Enstitüsü Dergisi 2016, 17, 67-91.

Develi, S. E. (2017). 21. yüzyılda göç olgusu: Uluslararası göç teorilerinin ekonomi politiği. Süleyman Demirel Üniversitesi, İktisadi İdari Bilimler Fakültesi Dergisi, 22(Göç Özel sayısı), 1343-1353.

Duyar, İ. ve Özener, B. (2003). Çocuk işçiler, çarpık gelişen bedenler. Ankara: Ütopya Yayınları.

Güneş, S. ve Kalayc1, A. R. (2004). Sokakta yaşayan/çalı̧̧an çocuklar: tespitler ve çözüm önerileri. Başbakanlık Aile ve Sosyal Araştırmalar Genel Müdürlüğ̈̈, 09.11.2018 tarihinde http://www.aile.gov.tr/ adresinden erişilmiştir.

Güngör, M. (2008), Evrensel bir sorun olarak çocuk suçluluğu ve sokakta çalış(tırıl)an ve yaşayan çocuklar. Adıyaman Üniversitesi Sosyal Bilimler Enstitüsü Dergisi, 1(1), 25-43.

ILO (2013). Marking Progress Against Child Labour: Global Estimates and Trends 2000-2012, Geneva. 09.11.2018 tarihinde https://www.ilo.org/wcmsp5/groups/public/---ed_norm/--ipec/documents/publication/wcms_221513.pdf adresinden erişilmiştir. 
ILO (2018). Çocuk işçiliği. 09.11.2018 tarihinde https://www.ilo.org/ankara/areas-of-work/child-labour/lang-tr/index.htm adresinden erişilmiştir.

İlik, B. ve Türkmen, Z. (1994). Sokaklarda çalışan ve Ankara sokaklarında çalışan çocuklar merkezine kaydı olan çocukların çalışma yaşamlarına ilişkin bir inceleme. Ankara: ILO/IPEC.

Karataş, A. vd. (1994). Antalya sokaklarında çalışan çocuklar üzerine bir araştırma. Dördüncü Ulusal Sosyal Hizmet Konferansı Bildiriler 3, 26-28 Mayıs, Ankara.

Karatay, A. (1999). Beyoğlu bölgesinde çalışan çocuklar ve aileleri.

S. Sayıta, M. Ruhi Şirin, 1. İstanbul Çocuk Kurultayı Araştırmalar Kitabı, İstanbul: İstanbul Çocukları Vakfı.

Kömürcü, B. ve Avşar N. N. (2016). Kentsel bir sorun alanı olarak sokakta çalış(tırıl)an- çalıştırılan çocuklar: Isparta örneği. Süleyman Demirel Üniversitesi İktisadi ve İdari Bilimler Fakültesi Dergisi, 21(3), 971-994.

Kuçur, F. (2016). Sosyo-ekonomik bir sorun olarak sokakta çalış(tırıl)an çocuklar. Uluslararası Ekonomik Araştırmalar Dergisi, 2(1), 55-66.

Memur-Sen (2019). Memur-Sen açlık ve yoksulluk rakamları açıklandı. 09.06.2019 tarihinde http://www.memursen.org.tr/aclik-yoksulluk-rakamlariaciklandi adresinden erişilmiştir.

Parin, S. (2012). Kent ve çocuk: Nakliyecilik/hamallık yapan çocuklar üzerine bir araştırma. (Ed. K. Alver), Kent Sosyolojisi İçinde (ss.447-459), Ankara: Hece Yayınları.

Şener, S. ve Serdar, M. (2015). Sokak çocukları problemi ve bu probleme yönelik uygulanan politikalar: Türkiye - Hindistan örneği. Dumlupinar Üniversitesi Sosyal Bilimler Dergisi, 45, 104-117

Şişman, Y. (2006). Sokakta çalış(tırıl)an çocukların yaşam koşulları ve gelecek beklentileri. Sosyal Bilimler Dergisi, 2, 251-275

Tekeli, İ. (1977). Bağımlı kentleşme. Ankara: Mimarlar Odası Yayınları.

TimeTurk (2018). Dünya üzerinde 152 milyon çocuk işçi var. Time Turk 02.12.2018 tarihinde https://www.timeturk.com/dunya-uzerinde152-milyon-cocuk-isci-var/haber-912453 adresinden erişilmiştir.

Türk, E. (2016). Hızl kentleşme sürecinin toplumsal yapıya etkileri: Batman örneği. Yayınlanmamış Doktora Tezi, Sakarya Üniversitesi Sosyal Bilimler Enstitüsü, Sakarya. 
Türk-İş (2019). Mayıs 2019 açlık ve yoksulluk sınırı. 09.06.2019 tarihinde http://www.turkis.org.tr/mayis-2019-aclik-ve-yoksulluk-sinirid236748 adresinden erişilmiştir.

UNICEF (2006). Önce çocuklar: Sokakta yaşayan velveya çalışan çocuklar. 03.12.2018tarihindehttps://www.unicef.org/turkey/dn_2006/_cp43.ht $\mathrm{ml}$ adresinden erişilmiştir.

Yalçın, C. (2004). Göç sosyolojisi. Ankara:Anı Yayıncılık.

\section{Kaynakça Bilgisi / Citation Information}

Türk, E. (2019). Batman'da Sokakta çalış(tırıl)an çocuklar ve karşı karşıya olduklari riskler. OPUS-Uluslararası Toplum Araştırmaları Dergisi, 13(19), 1126-1158. DOI: 10.26466/opus.580524 